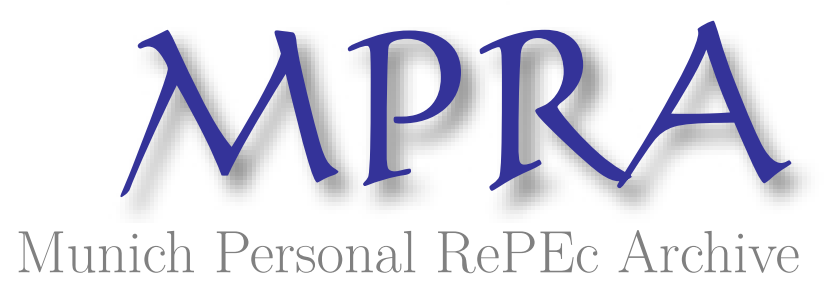

\title{
The significance of renewable energy use for economic output and environmental protection: Evidence from the next 11 developing economies
}

Paramati, Sudharshan Reddy and Sinha, Avik and Dogan, Eyup

Jiangxi University of Finance and Economics, China, Administrative Staff College of India, Abdullah Gul University

2017

Online at https://mpra.ub.uni-muenchen.de/100087/

MPRA Paper No. 100087, posted 05 May 2020 15:44 UTC 
The significance of renewable energy use for economic output and environmental protection: Evidence from the next 11 developing economies

\author{
Sudharshan Reddy Paramati \\ International Institute for Financial Studies \\ Jiangxi University of Finance and Economics, China \\ srparamati@jxufe.edu.cn \\ (Corresponding author)
}

\begin{abstract}
Avik Sinha
Centre for Economics and Finance, Administrative Staff College of India fl1aviks@iimidr.ac.in

Eyup Dogan

Department of Economics, Abdullah Gul University

eyup.dogan@agu.edu.tr
\end{abstract}




\title{
The significance of renewable energy use for economic output and environmental protection: Evidence from the next 11 developing economies
}

\begin{abstract}
Increasing economic activities in developing economies are raising demand for energy which is mainly sourced from conventional sources. The consumption of more conventional energy sources will have a significant negative impact on the environment. Therefore, the attention of the policy makers, recently, has shifted towards the promotion of renewable energy generation and uses across the economic activities to ensure the low carbon economy. Given the recent scenario, in this paper, we aim to examine the role of renewable energy consumption on the economic output and $\mathrm{CO}_{2}$ emissions of the next fastest developing economies of the world. The study makes use of annual data from 1990 to 2012 and employs several robust panel econometric models. The empirical findings confirm the significant long-run association among the variables. Similarly, the results show that the renewable energy consumption positively contributes to economic output and has an adverse effect on the $\mathrm{CO}_{2}$ emissions. Given our findings, we suggest the policy makers of those economies to initiate further effective policies to promote more renewable energy generation and uses across the economic activities to ensure sustainable economic development.
\end{abstract}

JEL classification: C23, O44, P28, Q01, R11

Keywords: Renewable energy consumption, Sustainable economic development, $\mathrm{CO}_{2}$ emissions, Developing economies 


\section{Introduction}

Energy consumption is a very important and fundamental aspect considering economic growth scenario of a nation. One of the predominant forms of energy consumed across the world is the fossil-fuel based energy. However, with the graduation of time, the energy consumption in emerging economies has been creating two prime problems, i.e. depletion of the non-renewable natural resources, and the emission of greenhouse gasses, like carbon dioxide $\left(\mathrm{CO}_{2}\right)$. Owing to these growing ecological issues, it is required to shift from nonrenewable to renewable energy sources, i.e. solar, the wind, tidal, waste, and several others. Compared to the non-renewable energy sources, the renewable energy sources are ecofriendly and nondepletable. Nations across the globe are gradually realizing the potential and significance of this new source of energy, and therefore, the share of renewable energy consumption in total energy use is rising. By the end of 2015, nearly 66 countries have issued biofuel mandate at central or provincial level (REN21, 2016).

The nexus between renewable energy consumption and environmental degradation may turn out to be a critical factor for the emerging economies. After the formation of BRIC in 2003, Goldman Sachs had identified the next generation of emerging economies, and this group of countries had been given the name of "Next 11" or N11 economies (Eghbal, 2008). These 11 countries are Bangladesh, Egypt, Indonesia, Iran, South Korea, Mexico, Nigeria, Pakistan, the Philippines, Turkey, and Vietnam. According to the World Development Indicators (WDI), published by the World Bank (2012), these countries account for nearly $8 \%$ of the global gross domestic product (GDP). At the same time, the U.S. Energy Information Administration has reported that these countries account for nearly $10 \%$ of global $\mathrm{CO}_{2}$ emissions (EIA, 2012). Graphical representation of this growth has been provided in Figure 1. As these countries are on a rapid economic growth path, therefore, the demand for energy in these nations is supposed to be very high. While satisfying this growing demand 
for energy, these nations should take care of the issue of environmental degradation without compromising the economic growth.

\section{[Insert Figure 1 here]}

If we look at the half-life of the ambient air pollutants, then the three most prevalent pollutants are (a) $\mathrm{NO}_{\mathrm{x}}$, with a half-life between 3 to 5 hours (Boon and Marletta, 2006), (b) $\mathrm{SO}_{2}$, with a half-life between 6 hours to 1 day (Brimblecombe, 1996), and (c) $\mathrm{CO}_{2}$, with halflife of nearly 27 years (Watkins and Mosobo, 1993). Now, these pollutants affect the atmospheric layers in different ways. Considering the emission affecting stratospheric region, $\mathrm{SO}_{2}$ is considered as the primary pollutant in this case, as the sulphur aerosols formed in this region are majorly caused by $\mathrm{SO}_{2}$ emission (Whitby, 1978). Apart from that, $\mathrm{SO}_{2}$ is soluble in airborne water globules, and thereby, forming sulphurus and sulphuric acid in the form of acid rains (Penkett et al., 1979). Formation of aerosols after reacting with particulate matters can create severe respiratory problems (Brain and Valberg, 1979), and even premature births (Hastwell, 1975). Mainly for these reasons, rise in the level of $\mathrm{SO}_{2}$ emission can cause serious damage to ambient atmosphere, and the human life. Now, if we look at the emission affecting tropospheric region, then the $\mathrm{NO}_{\mathrm{x}}$ should be considered as the primary pollutant in this case, as $79 \%$ of the tropospheric atmosphere consists of nitrogen $\left(\mathrm{N}_{2}\right)$. It is majorly responsible for creation of ground-level ozone, a primary component of smog. It is also responsible for creation of various nitrate compounds, which add to the level of respiratory particulate matters in the lower atmosphere. Owing to these reasons, rise in the level of $\mathrm{NO}_{\mathrm{x}}$ emission can cause serious damage to ambient atmosphere and human life. Now, for the case of $\mathrm{N}-11$ countries, it can be seen that these countries are highly dependent of fossil fuel consumption, and due to the high temperature of the power plants $\left(1500^{\circ} \mathrm{C}-1900^{\circ} \mathrm{C}\right)$, oxidization of sulphur particles and molecular $\mathrm{N}_{2}$ generate a substantial amount of greenhouse gases. Moreover, as these countries are still on the path of achieving a sustained 
industrialization, therefore, high vehicular density can be experienced in these nations, and this high vehicular transportation adds to the level of $\mathrm{SO}_{2}$ and $\mathrm{NO}_{\mathrm{x}}$ emissions in these nations (for developing nations, see Sinha and Bhattacharya, 2016, 2017). However, as the lifecycle of these two pollutants are comparatively smaller than $\mathrm{CO}_{2}$, which is also generated in these two processes mentioned, it exerts a more and sustained grievous effect on the atmosphere, and this scenario is particularly visible for the $\mathrm{N}-11$ economies.

In the light of the above discussion, this paper empirically examines the impact of renewable and non-renewable energy consumption on economic activities and $\mathrm{CO}_{2}$ emissions across a panel of Next 11 emerging economies over the period 1990-2012. For this purpose, we employ several robust panel econometric techniques. For instance, the long-run equilibrium relationship among the variables is explored using the Fisher-type Johansen panel cointegration test. The long-run output and emission elasticities are examined using the fully modified ordinary least squares (FMOLS) method and finally the short-run causal relationship between the variables is identified by employing heterogeneous panel noncausality test.

Given the rapid economic growth in these nations, it is important to understand the contribution of renewable energy for economic growth and to what extent it reduces $\mathrm{CO}_{2}$ emissions in these countries. The findings derived from this analysis will be crucial for the policy makers and government officials to take appropriate measures to meet the increasing demand for energy and also mitigating the growth of $\mathrm{CO}_{2}$ emissions due to the significant economic activities. One recent study by Shahbaz et al. (2016) was carried out on Next 11 economies. Following time-varying Granger causality approach, the authors found the evidence of conservation hypothesis for Bangladesh and Egypt, growth hypothesis for Philippines, Turkey, and Vietnam, feedback hypothesis for South Korea, and neutrality hypothesis for rest of the countries. In addition, Yildirim et al. (2014) investigated the causal 
relationship between aggregate energy consumption and economic growth for the Next 11 countries, and found the existing of growth hypothesis for Turkey and neutrality hypothesis for the rest. These studies divulge the fact that rest of the Next 11 economies are already in the process of energy conservation and environmental protection. However, these studies did not consider renewable energy while taking energy consumption into account for Next 11 economies. Taking a cue from these results, the present study may find its relevance in finding out the role of renewable energy consumption in stimulating economic growth and protecting the environment by lowering the growth of $\mathrm{CO}_{2}$ emissions. Apart from these studies, we have not come across any study, which focuses on disintegrating the causal impacts of renewable and non-renewable energy consumption on economic activities and $\mathrm{CO}_{2}$ emissions for Next 11 nations. Given this discussion, this study will make significant contributions to the body of knowledge and the policy on the issue of the relationship between renewable energy use, economic activities and $\mathrm{CO} 2$ emissions. The structure of the article is as follows: Section 2 deals with the review of relevant literature, Section 3 delineates the econometric techniques and data, Section 4 illustrates the empirical findings, and Section 5 summarizes the article with concluding remarks.

\section{Review of Literature}

The existing studies on the association between economic growth, energy consumption, and $\mathrm{CO}_{2}$ emission have been carried out extensively for the last two decades (Aslan and Gozbasi, 2016), and nearly all of the models are developed in bits and pieces (Dogan and Seker, 2016a). If these studies are categorized based on the contextual evidence, we can conclude that these studies are mostly carried out on the group(s) of developed, emerging, and less-developed economies. Our study is focused on the N11 emerging economies. We will review the existing studies carried out on these 11 economies. The review of the literature has been divided into two themes, namely (i) association between renewable energy 
and economic activities, and (ii) association between renewable energy and $\mathrm{CO}_{2}$ emissions. We discuss these two themes in the following subsections.

\subsection{Association between renewable energy consumption and economic activities}

In the existing literature of energy economics, the very concept of energy consumption coexists with economic activities, as energy consumption is the primary source for the economic activities. Inglesi-Lotz (2014) argued that renewable energies contribute to the economic conditions of countries. In the literature, this association between energy consumption and economic activities can be described in terms of four hypotheses, i.e. neutrality hypothesis, conservation hypothesis, growth hypothesis, and feedback hypothesis (Aslan and Ocal, 2016). All of the studies that have carried out on energy-growth nexus have found the evidence of these four hypotheses. In this section, we will review the literature on the effect of renewable energy consumption on economic activities, with special focus on emerging economies.

While assessing the causality between renewable energy consumption and economic activities, one of the foremost studies in this context was carried out by Chien and $\mathrm{Hu}$ (2007). They studied the association between real GDP, renewable energy consumption, capital stock, and labor for 45 developing and developed economies for the period of 2001-2002. By taking the data envelopment analysis (DEA) approach, they found that for the non-OECD countries, renewable energy has a significant impact on the capital formation and real GDP. Following ordinary least square (OLS), fully modified OLS, and dynamic OLS approach, Sadorsky (2009) studied 18 emerging economies for 1994-2003, and it was found that rise in the per capita income results in the rise in renewable energy consumption for the sample countries. Apergis and Payne (2010a) analyzed 13 Eurasian countries for 1992-2007 within a multivariate panel data framework including real GDP, renewable energy consumption, real gross fixed capital formation, and labor force. Using the FMOLS approach, they found that 
$1 \%$ increase in renewable energy consumption increases economic growth by $0.19 \%$; in addition, using heterogeneous panel cointegration test, they found the evidence of feedback hypothesis between renewable energy consumption and economic growth. Similarly, Apergis and Payne (2010b) investigated the relationship between real GDP, renewable energy consumption, capital and labor for the OECD countries for the period 1985-2005, and found that a $1 \%$ increase in renewable energy stimulates economic growth by $0.76 \%$ by applying the FMOLS long-run estimator.

Fang (2011) analyzed the effect of renewable energy consumption of per capita GDP for China during 1978-2008. This study found the evidence of growth hypothesis by applying OLS technique. Tiwari (2011) analyzed the causal association between renewable energy consumption and economic growth for India during 1960-2009. Following the variance decomposition, he found the causal association running from renewable energy consumption to economic growth, and thereby supporting the growth hypothesis. Bildirici (2012) analyzed the causal association between biomass energy consumption and economic growth for seven developing and emerging economies during 1980-2009. Following Autoregressive Distributed Lag (ARDL) bounds test and vector error correction model (VECM), the author found the evidence of feedback hypothesis. Al-mulali et al. (2013) analyzed the causal association between renewable energy consumption and GDP growth for 108 countries during 1980-2009. Using the fully modified OLS, they found the evidence of feedback hypothesis for 142 countries, neutrality hypothesis for 34 countries, and growth hypothesis for four countries.

Likewise, Pao and Fu (2013a) analyzed the impact of non-hydroelectric renewable energy consumption, total renewable energy consumption, non-renewable energy consumption, and the total primary energy consumption on real GDP for Brazil during 19802010. Following vector-error correction approach, they found the evidence of feedback 
hypothesis between total renewable energy consumption and real GDP, and the evidence of growth hypothesis between non-hydroelectric renewable energy consumption and real GDP. In a subsequent study, Pao and Fu (2013b) analyzed the impacts of total renewable energy, hydroelectric energy, non-hydroelectric renewable energy, nuclear energy, total nonrenewable energy, and fossil fuel energy consumptions on real GDP for Brazil during 19802009 following a production function approach. By applying the Granger causality test, they found the evidence of feedback hypothesis between (a) non-hydroelectric renewable energy consumption and real GDP, and (b) nuclear energy consumption and real GDP. They have also found the evidence of growth hypothesis between hydroelectric energy consumption and real GDP. Sebri and Ben-Salha (2014) studied causality between economic growth and renewable energy consumption in the BRICS countries for 1971-2010 following a multivariate framework. Using the ARDL bounds test and VECM, they found the existence of feedback hypothesis in this context. Ozturk and Bilgili (2015) analyzed the effect of biomass consumption on GDP growth for 51 Sub-Sahara African countries during 19802009. Following a heterogeneous panel analysis approach, they found that biomass consumption has a direct impact on GDP growth. Tugcu et al. (2012) provided a brief summary of the studies in this particular context.

Some of the recent evidence by Bhattacharya et al. (2016), Dogan (2015), Dogan (2016), Paramati, Ummalla et al. (2016), and several other researchers have extended the research on the renewable energy consumption and economic activities towards diverse aspects, and they have considered the dimensions, like tourism, foreign direct investment, labor market, capital market development, etc. under the multivariate frameworks. All of these studies have a special focus on the emerging economies, and this particular contextual aspect complies with the focus of the present study. 
The majority of these studies have considered GDP or real GDP as the indicator of economic activity and they failed to consider the potential determinants of economic activities in the model. Therefore, the present study addresses this gap by considering gross capital formation and labor force as two explanatory variables for economic activity, and on the other hand, this study considers both renewable and non-renewable energy as drivers of economic activity. Moreover, the present study has brought forth a new dimension by considering the next 11 emerging economies. In this way, this study addresses this existing gap in the literature for the emerging economies.

\subsection{Association between renewable energy consumption and $\mathrm{CO}_{2}$ emission}

In the field of energy economics, there has been a substantial volume of literature on the causal association between carbon dioxide $\left(\mathrm{CO}_{2}\right)$ emission and energy consumption or nonrenewable energy consumption in particular. Over the last few years, researchers are turning towards exploring the causal association between renewable energy consumption and $\mathrm{CO}_{2}$ emission. The studies have considered various geographical locations, a wide range of econometric tools, and a number of explanatory variables. We will review this causal association in this subsection.

While we consider the literature on the causality between renewable energy consumption and $\mathrm{CO}_{2}$ emission for emerging economies, one of the earliest studies was carried out by Sadorsky (2009). Following a bivariate framework, the author investigated the causal relationship for 18 emerging countries during 1994-2003. By employing Pedroni cointegration test (Pedroni, 2001b) and Granger causality test (Granger, 1969), the author found the evidence of conservation hypothesis in the long run and neutrality hypothesis in the short run. Apergis et al. (2010) studied the causal association between $\mathrm{CO}_{2}$ emission, renewable energy consumption, nuclear energy consumption and economic growth for 19 developed and developing countries for the period of 1984-2007. They found the evidence of 
feedback hypothesis between renewable energy and $\mathrm{CO}_{2}$ emission, and nuclear energy and $\mathrm{CO}_{2}$ emission, for the developing countries. Menyah and Wolde-Rufael (2010) studied the causal association between $\mathrm{CO}_{2}$ emissions, renewable and nuclear energy consumption and real GDP for the US during 1960-2007. Applying Granger causality test, they found the evidence of conservation hypothesis between renewable energy consumption and $\mathrm{CO}_{2}$ emissions, and growth hypothesis between nuclear energy consumption and $\mathrm{CO}_{2}$ emissions. Silva et al. (2012) analyzed the causal association between the share of renewable energy sources on electricity generation, GDP, and $\mathrm{CO}_{2}$ emissions for the US, Denmark, Portugal, and Spain during 1960-2004. Following a Structural Vector Autoregressive (SVAR) approach, they found the evidence of growth hypothesis between the share of renewable energy sources and $\mathrm{CO}_{2}$ emissions.

Similarly, Farhani (2013) analyzed the causal association between renewable energy consumption, economic growth and $\mathrm{CO}_{2}$ emissions for 12 MENA countries during 19752008. Following a panel cointegration approach, the author found the evidence of growth hypothesis in the short run and the evidence of conservation hypothesis in the long run. Apergis and Payne (2014) analyzed the causal association between renewable energy, per capita real GDP, $\mathrm{CO}_{2}$ emissions and crude oil prices for 25 OECD countries during 19802011. Following a panel cointegration and VECM approach, they found the evidence of feedback hypothesis between renewable energy consumption and $\mathrm{CO}_{2}$ emissions. Sebri and Ben-Salha (2014) analyzed the causal association between real GDP, renewable energy consumption, $\mathrm{CO}_{2}$ emissions, and trade openness for the BRICS countries during 1971-2010. Following ARDL Bounds testing approach, they found the evidence of conservation hypothesis between renewable energy consumption and $\mathrm{CO}_{2}$ emissions for India and South Africa. Zeb et al. (2014) analyzed the causal association between electricity production from renewable sources, $\mathrm{CO}_{2}$ emissions, natural resource depletion, GDP, and poverty for 5 
SAARC countries (Bangladesh, India, Nepal, Pakistan, and Sri Lanka) during 1975-2010. Following panel Granger causality approach, they found the evidence of neutrality hypothesis between electricity production from renewable sources and $\mathrm{CO}_{2}$ emissions, whereas, following the FMOLS approach they found the evidence of growth hypothesis between them.

Some of the recent evidence by Apergis and Payne (2015), Dogan and Seker (2016a), Dogan and Seker (2016b), Jebli (2016), Mbarek et al. (2016), and several other researchers have extended the research on the renewable energy consumption and $\mathrm{CO}_{2}$ emissions in diverse contexts and the results of these studies in this particular strand of the literature are inconclusive yet.

The majority of these studies have considered GDP or real GDP within the frameworks. The present study considers per capita GDP and population as two explanatory variables for $\mathrm{CO}_{2}$ emissions, and on the other hand, the other two explanatory variables are renewable and non-renewable energy consumptions. In this way, this study can disintegrate the causal impacts of renewable and non-renewable energy consumptions on $\mathrm{CO}_{2}$ emissions. Moreover, the present study has brought forth a new dimension by considering the next 11 emerging economies. In this way, this study addresses this existing gap in the literature for the emerging economies.

\section{Institutional background}

The rapid economic growth of the Next 11 economies calls for increasing level of energy consumption at every stage of the industrialization process. Starting from the primary sector to tertiary sector, the consumption of energy, in the form of commercial electricity is enabling the industrial growth in these economies. As these economies are both developing and newly industrialized in nature, the investment attractiveness catalyzes their economic growth, and it is visible from their GDP growth rate compared to the global average (Fig. 2). As on 2012, these countries account for nearly 8.24 percent of the world economy, 10.76 percent of the 
global non-renewable energy consumption, and 9.86 percent of global $\mathrm{CO}_{2}$ emission (EIA, 2012; World Bank, 2012). During 1990-2012, the per capita income of these countries has grown nearly 87.26 percent, whereas the global per capita income has grown only 37.20 percent (World Bank, 2012). The urbanization process in these economies is also evolving in keeping with the pace of the economic growth.

\section{[Insert Figure 2 here]}

In the face of rising economic activity in the Next 11 economies, these economies are facing the problem of rising greenhouse gas (GHG) emissions, similar to other developing countries. Therefore, the governments of these nations are bringing forth energy policy initiatives to boost the renewable energy sector, and in doing so, these countries are embarking on solar, wind, hydro, biomass, and hybrid energy projects. The renewable energy policy of Bangladesh is targeting the renewable energy generation to reach 10 percent of total energy production by 2020 (Bangladesh Power Development Board, 2016). In order to institutionalize the renewable energy generation process, Bangladesh Power Development Board came up with Directorate of Renewable Energy and Research \& Development in 2010.

The Egyptian government is aiming at 20 per cent share of renewable energy of total energy production by 2022 , as they are being faced with energy shortage issues, resulting in obstacles in the economic growth and development process. The government has allotted nearly 7,650 square kilometers of land for producing $87 \mathrm{GW}$ of renewable energy (Burger, 2015).

Just similar to Egypt, access to electricity is also a major problem for Indonesia, and this problem is prevalent in the rural areas. In keeping with the rising demand for electricity in coming years, the government of Indonesia is increasing the share of renewable energy in total energy mix to 25 percent by 2025 , and for achieving this objective, the government 
planned to increase the investment in the renewable energy sector by USD 38 billion (Mahapatra, 2016).

For the case of Iran, the government is planning to increase the renewable energy generation capacity by 5,000 MW by 2018 , as a part of their sixth development plan, and the investment in this sector is projected to be USD 10 billion by 2018 and USD 60 billion by 2025 (Wheeler and Desai, 2016). This plan is aimed at enhancing the energy security of Iran.

The government of Korea is planning to invest USD 150 billion at the initial stage of the capacity building process for renewable energy, and in doing so, they are targeting to increase the share of renewable energy to 11 percent by 2035 (Shin, 2015). The process includes investing in the international clean energy market and implementing energy efficient building for reducing energy wastage.

Following the 2014 Special Programme for the Use of Renewable Energy (PEAER), the government of Mexico has set up the target to increase the share of renewable energy to 24.9 percent by 2018,35 percent by 2024 , and 40 per cent by 2035 , and 50 per cent by 2050 (Cabré et al., 2015). Mexico's Electricity Law of 2014 is enforcing the power generation firms to adhere to Clean Energy Certificate guidelines in order to meet the mentioned targets.

In order to reduce rapid depletion of natural resources, to meet the growing demand of energy, and to ensure energy security, the government of Nigeria has introduced Vision 20, according to which 10 per cent of total energy mix should come from hydropower, 3 percent from solar power, and 5 percent from wind and biomass by 2020 (Ministry of Power, 2015). The total share of renewable energy is projected to be 20 percent of the total energy mix by 2030.

In order to fight the rural electrification issue, the government of Pakistan is moving towards implementing off-grid solar energy system with a capacity of $3 \mathrm{GW}$ (Awan, 2015). The Alternative Energy Development Board of Pakistan is trying to explore every possible 
opportunity for renewable energy generation for reducing the mounting dependence on crude oil, and at the same time, using the renewable energy as a solution to address the issue of social imbalance. Presently, they are focusing on solar and wind energy generation as the renewable energy solution.

As a part of National Renewable Energy Program, the government of the Philippines is targeting to double the renewable energy generation capacity by 2030 . As a part of this program, the capacity of hydropower should be increased by 5,400 MW, biomass energy by $265 \mathrm{MW}$, solar energy by $280 \mathrm{MW}$, and tidal energy by $10 \mathrm{MW}$. While doing this, the government is also taking sufficient initiatives to educate the people for increasing the acceptability of the renewable energy (Fronda, 2015).

For reducing the dependence on natural gas, the government of Turkey has planned to increase the share of renewable energy in the total energy production by 30 percent by 2023 , and as a part of this plan, all available sources of hydropower will be exploited, wind power generation will be increased to $20 \mathrm{GW}$, and geothermal power to $600 \mathrm{MW}$ (Bölük, 2013). This plan is made for commensuration of the growing demand of energy in Turkey in a selfsustained manner. Along with this, Turkish Energy Regulatory Agency (EMRA) announced biofuel blending to be compulsory for bioethanol, starting from 2013, and biodiesel, starting from 2014.

Lastly, the energy demand in Vietnam is going to be almost four times compared to that in 2012 by 2030 , whereas the electricity demand is expected to rise more than ten times by the same time. This problem coexists with the problem regarding rural electrification and dependence on non-renewable fossil fuel. In order to address these issues, the government of Vietnam is targeting hydropower, wind, solar, biogas, and biofuel as the way to implement renewable energy solutions. As per the Renewable Energy Development Strategy, the share of renewable energy in the energy mix is expected to reach 32.3 percent by 2030 (Noi, 2016). 
According to the General Department of Energy, the government of Vietnam, achievement of this plan may address the issue of access to electricity and dependence on fossil fuel, at the same time.

As a whole, the Next 11 economies are experiencing the need of renewable energy for sustaining their economic growth, and therefore, the government and regulatory infrastructure are supporting them in achieving the renewable energy initiatives. In this way, they will be able to shift from fossil fuel based energy to clean energy resources, and in doing so, curb down the GHG emissions.

\section{Data and methodology}

\subsection{Nature of data and measurement}

The present section describes the nature of data, measurement and the list of countries that are considered in this study. We considered the next 11 countries that are believed to be the fastest developing in the world. This study constructs panel data set by making use of annual data from 1990 to 2012 (23 observations for each cross-section) on 11 developing economies. The considered countries are as follows: Bangladesh, Egypt, Indonesia, Iran, Korea, Mexico, Nigeria, Pakistan, the Philippines, Turkey and Vietnam.

The measurement of the variables is as follows: $\mathrm{CO}_{2}$ emissions (CDE) are measured as total carbon dioxide emissions from the consumption of energy in million metric tons; economic activities (EA) are measured as gross domestic product at market prices in constant 2010 US\$; non-renewable energy consumption (NREC) is the sum of coal, gas and petroleum in Quadrillion Btu; renewable energy consumption (REC) includes hydro, modern and traditional biomass, wind, solar, liquid biofuels, biogas, geothermal, marine and waste sources in Terajoule (TJ); capital (CAP) is measured through the gross fixed capital formation in constant 2010 US\$; labour (LBR) is the total working population who are aged 15 and above; per capita income (PI) is measured through the gross domestic product divided 
by the midyear population, and finally population (POP) is the total population which counts all residents regardless of legal status or citizenship. The considered annual data on CDE and NREC are obtained from the US Energy Information Administration (EIA) online database while EA, CAP, LBR, PI and POP are sourced from the World Development Indicators (WDI) online database published by the World Bank and finally REC is acquired from the Sustainable Energy for All published by the World Bank.

The above variables are measurement in different units; therefore it is important to convert all of these variables into a uniform measurement before commencing any empirical analysis. By following the previous literature (Alam, Paramati et al., 2016; Bhattacharya et al., 2016; Paramati, Ummalla et al., 2016), we transformed all of the variables into natural logarithms to overcome from the problems that are associated distributional properties of the data series. As argued by Paramati, Ummalla et al. (2016), the estimated coefficients from the $\log$ converted series can be interpreted as the elasticities.

\subsection{Model specification}

Since the objectives of this study is to examine the effect of renewable and non-renewable energy consumption on the economic activities and $\mathrm{CO}_{2}$ emissions across a panel of developing economies. To achieve these objectives, we develop the following models using the existing theoretical approaches such as neo-classical growth model and IPAT environmental model (Ehrlich and Holdren, 1971) to determine the economic output and $\mathrm{CO}_{2}$ emissions, respectively. We discuss these models in the following:

To empirically examine the effect of non-renewable and renewable energy consumptions on the economic output, we use the following model:

$E A_{i t}=f\left(C A P_{i t}, L B R_{i t}, N R E C_{i t}, R E C_{i t}, v_{i}\right)$

where, EA, CAP, LBR, NREC and REC represent for economic activities, capital, labor, nonrenewable and renewable energy consumptions, respectively. $v_{i}$ represents for individual 
fixed country effects, countries and time period are indicated by the subscripts $i(i=1, \ldots, \mathrm{N})$ and $t(t=1, \ldots, \mathrm{T})$, respectively.

Similarly, to identify the determinants of $\mathrm{CO}_{2}$ emissions, the previous studies base their empirical analyses on the IPAT model (Raskin, 1995; York et al., 2002; Paramati, Alam et al., 2016). This approach is framed on the baseline relationship among population, income, technology and environmental impact as presented in the following equation:

$I=P \times A \times T$

where, $I$ is the pollution or environmental impact which is sourced from the population $(P)$, the level of economic activities or per capita consumption - $(A)$ and the technological level or efficiency defined by the amount of pollution per unit of economic activity or consumption (T). This basic model is further extended, by Dietz and Rosa $(1994,1997)$, to a stochastic version which is popularly known as the STIRPAT (STochastic Impacts by Regression on Population, Affluence and Technology) model. This model is considered to be no longer just an accounting equation, but it can be used to test the hypotheses empirically. Thus, following the common specification of STIRPAT model, we frame the following equation for our empirical analysis:

$C D E_{i t}=f\left(P O P_{i t}, P I_{i t}, N R E C_{i t}, R E C_{i t}, v_{i}\right)$

where, $\mathrm{CO}_{2}$ emission is a function of population, per capita income, non-renewable energy consumption and renewable energy consumption. The model in Eq. (3), aims to address the impact of non-renewable and renewable energy consumptions on the $\mathrm{CO}_{2}$ emissions by accounting other determinants including population and per capita income in the model.

\subsection{Panel unit root tests}

The first step of the empirical analysis is to examine the order of integration of the variables. This is an important issue to be considered as it determines the selection of the models for empirical analysis. Given that we choose two different panel unit root tests to 
examine the distributional properties of the data series. For instance, the common unit root process is examined using Levin et al. (2002) (LLC) test, while the individual unit root process are investigated by employing Im et al. (2003) (IPS) test. As reported previously, the application of these unit root tests is very important in identifying the order of integration of the variables. For instance, if all of the variables are integrated in the order of one or I (1), then this indicates that all of the variables are non-stationary at levels and stationary at their first order differentials. This suggests that these variables, as a group, may have a cointegration relationship in the long-run.

\subsection{Panel cointegration test}

We employ a panel cointegration technique to investigate the long-run equilibrium relationship among the variables. The panel cointegration technique is most useful, if a time series element of each cross-section is short (Alam and Paramati, 2015). Due to this advantage, researchers started using the panel cointegration approach to examine the long-run equilibrium relationship among the variables. In this study, we apply Fisher-type Johansen cointegration methodology which is proposed and developed by Maddala and Wu (1999).

The Fisher-type panel cointegration methodology uses Johansen (1991) approach. Maddala and $\mathrm{Wu}$ (1999) argue that this panel cointegration test is more robust than the conventional cointegration tests, which are based on the Engle-Granger two-step approach. This method uses two ratio tests, such as, trace test and maximum eigenvalue test to identify the number of cointegrating vectors. The findings of both trace and max-eigen tests can be utilized to determine the presence of cointegrating vectors. However, these two tests may not always provide equal number of cointegrating vectors. If both tests do not provide the same number of cointegrating vectors, then we can draw the conclusions based on the max-eigen test as it carries the independent analysis on each eigenvalue. 


\subsection{Long-run elasticities}

We also estimate a single cointegrating vector, based on the Equation (1) and (3). The first equation determines economic output elasticities, while the second one examines the $\mathrm{CO}_{2}$ emission elasticities. In regard to the panel data set, the application of ordinary least squares (OLS) on Equation (1) and (3) is asymptotically biased and its distribution relies upon nuisance parameter. Pedroni $(2000,2001 \mathrm{a})$ argues that in the course of regression estimation the nuisance parameters can result due to the presence of serial correlation and endogeneity among the regressors. Therefore, to address these issues, we employ FMOLS model based on the approach suggested by Pedroni $(2000,2001 \mathrm{a}) .{ }^{1}$ This approach utilizes a non-parametric approach to address the issues of endogeneity and serial correlation, which may be present in the model.

\subsection{Heterogeneous panel causality test}

Finally, we aim to identify the direction of short-run dynamic bivariate panel causality among the variables by using a model that supports the presence of heterogeneity across the cross-sections. ${ }^{2}$ A simple approach is proposed by Dumitrescu and Hurlin (2012) for testing the null hypothesis of homogeneous non-causality against the alternative hypothesis of heterogeneous non-causality. This test has to be applied to the stationary data series using the fixed coefficients in a vector autoregressive (VAR) framework. The significance of this test is that it allows for having dissimilar log structures and also heterogeneous unrestricted coefficients across the cross-sections under both hypotheses. Under the null hypothesis, no causality in any cross-section is tested against the alternative hypothesis of causality at least for a few cross-sections. The Wald statistics for testing Granger non-causality are computed

\footnotetext{
${ }^{1}$ The FMOLS model has been widely used by several authors to examine the long-run elasticities of the variables (e.g. Alam et al. 2015; Bhattacharya et al. 2016).

${ }^{2}$ The previous literature (e.g. Alam and Paramati, 2015) used the conventional approach (i.e., VECM technique) to identify the causal relationship among the variables. This model suffers from numerous disadvantages and as a result of this, the recent literature (e.g. Alam and Paramati 2016; Paramati, Apergis et al. 2017; Paramati, Shahbaz et al. 2017) has started to employ the heterogeneous panel non-causality test to explore the direction of causality between the variables.
} 
for each of the cross-sections separately. Then, the panel test value is acquired by taking the cross-sectional average of individual Wald statistics. Dumitrescu and Hurlin (2012) argue that this panel test value converges to a normal distribution under the homogeneous noncausality hypothesis when $T$ goes to infinity first, and then $N$ also goes to infinity.

The correlations among the variables are displayed in Table 1. As expected, the results show that $\mathrm{CO}_{2}$ emissions are positively correlated with economic output and non-renewable energy consumption while it is negatively correlated with renewable energy consumption. This implies that there is a significant negative association between $\mathrm{CO}_{2}$ emissions and renewable energy consumption. This can be further argued that as the renewable energy consumption increases across the economic activities then there is a potential chance of reducing $\mathrm{CO}_{2}$ emissions. Similarly, the relationship between non-renewable energy consumption and economic output is positive; however renewable energy consumption seems to be associated negatively with economic output. One possible explanation for renewable energy to have a negative relationship with economic output is due to the transition period, as these economies are recently moving from the use of non-renewable energy to the renewable energy. Hence, it is possible to have a negative relationship with economic output when countries are moving from one energy source to the other. However, we will confirm the nature of relationship between renewable energy use and economic output by employing rigorous econometric models in the following sections.

\section{[Insert Table 1 here]}

\section{Empirical findings and discussion}

\subsection{Order of integration of the variables}

As we have discussed earlier, we employ two panel unit root tests on the data, and both the tests are of first generation, in nature. However, before carrying out the first generation unit root tests, we conducted Pesaran (2004) test to check the cross section dependence in the 
data. The null hypothesis of this test is that the cross sections are independent, and it is computed based on the average of pair-wise correlation coefficients of the ADF regression residuals for each unit. The test statistics are recorded in Table 2, and they show that the null hypothesis cannot be rejected. It signifies that the cross sections of all the panels are independent, and therefore, the first generation panel unit root tests can be applied.

\section{[Insert Table 2 here]}

The order of integration of the variables is explored using two different panel unit root tests. The results of these tests are displayed in Table 3. Both these tests have the null hypothesis of a unit root (non-stationary) as against the alternative hypothesis of no unit root (stationary). The results of these tests confirm the acceptance of null hypothesis at levels for all of the variables. However, when these tests are applied to the first difference of the series, the null hypothesis is strongly rejected for all of the variables at the $1 \%$ significance level. This indicates that all of the variables have the same order of integration, i.e. they are of I(1) in nature. This implies that there may be a cointegration relationship among the variables of Equation (1) and (3) in the long-run. This is explored in the following section.

\section{[Insert Table 3 here]}

\subsection{Analysis of long-run equilibrium relationship}

The above panel unit root tests confirmed that all the variables under consideration have the same order of integration. Therefore, we apply Fisher-type Johansen panel cointegration test to explore the long-run equilibrium relationship among the variables of Equation (1) and (3). The results of this test are reported in Table 4. The results show that there is a significant long-run equilibrium relationship among economic output, non-renewable and renewable energy consumptions. Similarly, the results also confirm the long-run equilibrium relationship among $\mathrm{CO}_{2}$ emissions, population, per capita income, non-renewable and renewable energy consumptions in a panel of next 11 developing economies. These findings 
suggest that the economic output and $\mathrm{CO}_{2}$ emissions share a significant long-run association with non-renewable and renewable energy consumptions. The results imply that these variables as a group may reach an equilibrium point in the long-run.

\section{[Insert Table 4 here]}

\subsection{The long-run economic output and $\mathrm{CO}_{2}$ emission elasticities}

The above analyses only confirm the long-run association among the variables and do not imply whether non-renewable and renewable energy consumptions have a positive or negative impact on the economic output and $\mathrm{CO}_{2}$ emissions. Therefore, we employ FMOLS technique on Equation (1) and (3) to explore the long-run elasticities of economic output and $\mathrm{CO}_{2}$ emissions, respectively. The empirical results of these models are presented in Table 5. The results of Equation (1) show that a $1 \%$ increase in non-renewable and renewable energy consumptions leads to rise in the economic output by $0.149 \%$ and $0.157 \%$, respectively. This suggests that the renewable energy consumption has more positive effect on the economic output than that of non-renewable energy consumption in the next 11 developing economies. Similarly, the results of Equation (3) show that a $1 \%$ rise in non-renewable energy consumptions increases the $\mathrm{CO}_{2}$ emissions by $1.076 \%$, while $1 \%$ rise in renewable energy consumption reduces $\mathrm{CO}_{2}$ emissions by $0.052 \%$. These findings reveal that non-renewable energy consumption positively contributes to $\mathrm{CO}_{2}$ emissions, while renewable energy consumption adversely affects its growth.

\section{[Insert Table 5 here]}

Given these findings, we argue that renewable energy consumption has a significant positive effect on the economic output, and it also catalyzes the reduction of $\mathrm{CO}_{2}$ emissions from these rapidly developing economies. Therefore, we suggest the policy makers to initiate effective policies to promote the renewable energy generation and uses across the economic activities, which eventually ensure sustainable economic development in these economies. 
On the other hand, the non-renewable energy consumption promotes environmental degradation by increasing the $\mathrm{CO}_{2}$ emissions. The non-renewable energy consumption has a positive impact on the economic output, but it has a large contribution to the $\mathrm{CO}_{2}$ emissions. Hence, this implies that the non-renewable energy consumption has to be discouraged and renewable energy generation and use should be incentivized for a sustainable environment.

\subsection{Direction of causality}

This section of the paper aims to examine the short-run causal relationship among the considered variables. For this purpose, we employ heterogeneous panel non-causality test based on the approach suggested by Dumitrescu and Hurlin (2012). The results of this test are reported in Table 6. The findings show that the non-renewable energy consumption Granger causes $\mathrm{CO}_{2}$ emissions, while $\mathrm{CO}_{2}$ emissions Granger causes renewable energy consumption. Further, we also found unidirectional causality that runs from non-renewable energy consumption to the renewable energy consumption in the short-run. In all others pairs, we didn't find statistical significance. These findings imply that higher consumption of nonrenewable energy may aggravate $\mathrm{CO}_{2}$ emissions and rising $\mathrm{CO}_{2}$ emissions may cause higher usage of renewable energy across economic activities. Further, higher consumption of nonrenewable energy also causes for higher use of renewable energy through the energy demand factor. Given that, our results show the significant association among $\mathrm{CO}_{2}$ emissions, nonrenewable and renewable energy consumptions in the short-run across a panel of next 11 developing economies.

\section{[Insert Table 6 here]}

\subsection{Country-specific long-run output and emission elasticities}

We further aim to examine the country-specific long-run output and emission elasticities across the sample countries. The empirical findings on economic output elasticities for each of the individual countries are displayed in Table 7. The results show that the renewable 
energy consumption has a significant positive effect on the economic output in Bangladesh, Egypt, Indonesia, Iran, Korea, Mexico, Nigeria and Pakistan, while it has a negative impact in the Philippines, and it is not statistically significant for Turkey and Vietnam. These findings imply that out of the 11 sample countries, the renewable energy consumption positively affects economic growth in 8 countries, while it is negatively influenced in 1 country. This can be further interpreted that the countries, where renewable energy consumption positively drives economic growth, should continue to use the policies, which are promoting the renewable energy generation and uses across the economic activities, as this will ensure the sustainable economic development. Similarly, the policy makers of the country, where renewable energy consumption is adversely affecting economic growth, have to be more careful in terms of transiting energy sources from non-renewable to the renewable, so as to minimize the economic slowdown due to the shift in energy sources.

\section{[Insert Table 7 here]}

Similarly, the country-specific long-run $\mathrm{CO}_{2}$ emission elasticities are reported in Table 8 . The results show that renewable energy consumption significantly reduces $\mathrm{CO}_{2}$ emissions in Bangladesh, Egypt, Nigeria, Pakistan, the Philippines, Turkey and Vietnam, while it positively contributes in Iron and Korea. The findings suggest that out of the 11 sample countries, the renewable energy consumption significantly declines $\mathrm{CO}_{2}$ emissions growth in 7 countries, while it adds a small amount to the emissions in 2 countries. However, it is not statistically significant for Indonesia and Mexico. From these findings, we can argue that the use of renewable energy mostly decline the growth in $\mathrm{CO}_{2}$ emissions in these economies. Given that, we suggest the policy makers of those countries to initiate more effective policies to promote the renewable energy use, which will not only ensure their transformation towards being low carbon economies but will also make a path towards sustainable economic development. 


\section{[Insert Table 8 here]}

\section{Conclusion and policy implications}

The current debate among the policy makers and environmental scientists is to fight against the growth of $\mathrm{CO}_{2}$ emissions across the globe. The statistics show that the developed economies have shown significant improvement in controlling the $\mathrm{CO}_{2}$ emissions by increasing the share of renewable energy consumption in total energy use. However, it is still a growing concern among the individuals and policy makers of the developing economies due to higher growth of $\mathrm{CO}_{2}$ emissions, which is mainly because of the increasing demand for energy from various economies activities. The major form of energy used in developing economies is the non-renewable energy, consumption of which generates a higher level of $\mathrm{CO}_{2}$ emissions. As a result, in the recent past, the policy makers and government officials of those developing economies have been aiming to promote the generation and use of renewable energy across the economic activities. Given the current debate, this study aimed to examine to what extent renewable energy consumption affects economic output and $\mathrm{CO}_{2}$ emissions across a panel of next 11 developing economies. For this purpose, the present study utilized annual data from 1990 to 2012 and employed robust panel econometric models.

The empirical findings of cointegration models indicate the long-run equilibrium relationship among the variables of economic output and renewable energy consumption and also $\mathrm{CO}_{2}$ emissions and renewable energy consumption. Further, our results show that the renewable energy consumption has a significant positive and negative effect on the economic output and $\mathrm{CO}_{2}$ emissions, respectively. Largely, the country-specific analysis also suggests that the renewable energy consumption has a significant positive and negative effect on the economic output and $\mathrm{CO}_{2}$ emissions, respectively. Given these findings, our study makes an important contribution to the body of knowledge and also to the policy. More specifically, our results suggested that the renewable energy consumption has more positive effect on the 
economic output than those of non-renewable energy sources. Therefore, we suggest the policy makers and government officials of those developing economies to initiate further effective policies to promote the generation and use of renewable energy across the economic activities. This will increase not only economic output but also reduce $\mathrm{CO}_{2}$ emissions. The significant consumption of renewable energy ensures a transformation towards low carbon economy and makes a path towards sustainable economic development. Our results also show that the renewable energy consumption leads to reduce the $\mathrm{CO}_{2}$ emissions in those economies. Therefore, it is worth promoting the consumption of renewable energy for higher economic development with lower $\mathrm{CO}_{2}$ emissions, at least in the case of next 11 economies.

\section{References}

Alam, M.S., Paramati, S.R., 2015. Do oil consumption and economic growth intensify environmental degradation? Evidence from developing economies. Applied Economics, 47(48), 5186-5203.

Alam, M.S., Paramati, S.R., 2016. The impact of tourism on income inequality in developing economies: Does Kuznets curve hypothesis exist?. Annals of Tourism Research, 61, 111-126.

Alam, M. S., Paramati, S. R., Shahbaz, M., Bhattacharya, M., 2016. Natural gas, trade and sustainable growth: empirical evidence from the top gas consumers of the developing world. Applied Economics, 1-15.

Al-mulali, U., Fereidouni, H.G., Lee, J.Y., Sab, C.N.B.C., 2013. Examining the bi-directional long run relationship between renewable energy consumption and GDP growth. Renewable and Sustainable Energy Reviews, 22, 209-222.

Apergis, N., Payne, J.E., 2010a. Renewable energy consumption and growth in Eurasia. Energy Economics, 32(6), 1392-1397.

Apergis, N., Payne, J. E., 2010b. Renewable energy consumption and economic growth: evidence from a panel of OECD countries. Energy policy, 38(1), 656-660.

Apergis, N., Payne, J.E., 2014. The causal dynamics between renewable energy, real GDP, emissions and oil prices: evidence from OECD countries. Applied Economics, 46(36), 4519-4525.

Apergis, N., Payne, J.E., 2015. Renewable energy, output, carbon dioxide emissions, and oil prices: evidence from South America. Energy Sources, Part B: Economics, Planning, and Policy, 10(3), 281-287.

Apergis, N., Payne, J.E., Menyah, K., Wolde-Rufael, Y., 2010. On the causal dynamics between emissions, nuclear energy, renewable energy, and economic growth. Ecological Economics, 69(11), 2255-2260.

Aslan, A., Gozbasi, O., 2016. Environmental Kuznets curve hypothesis for sub-elements of the carbon emissions in China. Natural Hazards, 82(2), 1327-1340.

Aslan, A., Ocal, O., 2016. The role of renewable energy consumption in economic growth: Evidence from asymmetric causality. Renewable and Sustainable Energy Reviews, 60, 953-959. 
Awan, A.A., 2015. Renewable Energy in Pakistan: Potential and Prospects. Alternative Energy Development Board, Government of Pakistan.

Bangladesh Power Development Board, 2016. Development of Renewable Energy Technologies by BPDB. Retrieved from: http://www.bpdb.gov.bd/bpdb/index.php?option=com_content\&view=article\&id=26

Bhattacharya, M., Paramati, S.R., Ozturk, I., Bhattacharya, S., 2016. The effect of renewable energy consumption on economic growth: Evidence from top 38 countries. Applied Energy, 162, 733-741.

Bildirici, M.E., 2012. The relationship between economic growth and biomass energy consumption. Journal of Renewable and Sustainable Energy, 4(2), 5.

Bölük, G., 2013. Renewable Energy: Policy Issues and Economic Implications in Turkey. International Journal of Energy Economics and Policy, 3(2), 153-167.

Boon, E.M., Marletta, M.A., 2006. Sensitive and selective detection of nitric oxide using an H-NOX domain. Journal of the American Chemical Society, 128(31), 10022-10023.

Brain, J.D., Valberg, P.A., 1979. Deposition of aerosol in the respiratory tract 1-3. American Review of Respiratory Disease, 120(6), 1325-1373.

Brimblecombe, P., 1996. Air Composition and Chemistry. Cambridge University Press, Cambridge.

Burger, A., 2015. Egypt's Renewable Energy Drive Gains Steam. Renewable Energy World. June 9, 2015. Retrieved from: http://www.renewableenergyworld.com/articles/2015/06/egypt-srenewable-energy-drive-gains-steam.html

Cabré, M.M., Lopez-Peña, A., Kieffer, G., Khalid, A., Ferroukhi, R., 2015. Renewable Energy Policy Brief: MEXICO. International Renewable Energy Agency (IRENA), Abu Dhabi.

Chien, T., Hu, J.L., 2007. Renewable energy and macroeconomic efficiency of OECD and non-OECD economies. Energy Policy, 35(7), 3606-3615.

Dietz, T., Rosa, E.A., 1994. Rethinking the environmental impacts of population, affluence and technology. Human Ecology Review, 1, 277-300.

Dietz, T., Rosa, E.A., 1997. Effects of population and affluence on CO2 emissions. Proceedings of the National Academy of Sciences, 94(1), 175-179.

Dogan, E., 2015. The relationship between economic growth and electricity consumption from renewable and non-renewable sources: A study of Turkey. Renewable and Sustainable Energy Reviews, 52, 534-546.

Dogan, E., 2016. Analyzing the linkage between renewable and non-renewable energy consumption and economic growth by considering structural break in time-series data. Renewable Energy, 99, 1126-1136.

Dogan, E., Seker, F., 2016a. Determinants of $\mathrm{CO}_{2}$ emissions in the European Union: The role of renewable and non-renewable energy. Renewable Energy, 94, 429-439.

Dogan, E., Seker, F., 2016b. The influence of real output, renewable and non-renewable energy, trade and financial development on carbon emissions in the top renewable energy countries. Renewable and Sustainable Energy Reviews, 60, 1074-1085.

Dumitrescu, E.I., Hurlin, C., 2012. Testing for Granger non-causality in heterogeneous panels. Economic Modelling, 29(4), 1450-1460.

Eghbal, M., 2008. The Next 11 Emerging Economies. Euromonitor International. Retrieved from: http://blog.euromonitor.com/2008/02/the-next-11-emerging-economies.html.

Ehrlich, P.R., Holdren, J.P., 1971. Impact of population growth. Science, 171(1), 1212-1217.

Fang, Y., 2011. Economic welfare impacts from renewable energy consumption: the China experience. Renewable and Sustainable Energy Reviews, 15(9), 5120-5128.

Farhani, S., 2013. Renewable energy consumption, economic growth and $\mathrm{CO}_{2}$ emissions: Evidence from selected MENA countries. Energy Economics Letters, 1(2), 24-41. 
Fronda, A.D., 2015. Philippines Renewable Energy Policy Updates. Renewable Energy Management Bureau, Department of Energy.

Granger, C.W.J., 1969. Investigating Causal Relations by Econometric and Cross-Spectral Methods. Econometrica, 37(3), 424-438.

Hastwell, G., 1975. Salbutamol aerosol in premature labour. The Lancet, 306(7946), 1212-1213.

Im, K. S., Pesaran, M. H., Shin, Y., 2003. Testing for unit roots in heterogeneous panels. Journal of Econometrics, 115(1), 53-74.

Inglesi-Lotz, R., 2014. The Impact of Renewable energy consumption to economic welfare: A panel data application. Energy Economics, 53, 58-63.

Jebli, M.B., 2016. On the causal links between health indicator, output, combustible renewables and waste consumption, rail transport, and $\mathrm{CO}_{2}$ emissions: the case of Tunisia. Environmental Science and Pollution Research, 1-17.

Johansen, S., 1991. Estimation and hypothesis testing of cointegration vectors in Gaussian vector autoregressive models. Econometrica, 59(6), 1551-1580.

Levin, A., Lin, C.F., Chu, C.S.J., 2002. Unit root tests in panel data: asymptotic and finite-sample properties. Journal of Econometrics, 108(1), 1-24.

Maddala, G.S, Wu, S., 1999. A comparative study of unit root tests with panel data and a new simple test. Oxford Bulletin of Economics and statistics, 61, 631-652.

Mahapatra, S., 2016. Indonesia Plans To Set Up Renewable Energy Utility. Clean Technica. January 12, 2016. Retrieved from: https://cleantechnica.com/2016/01/12/indonesia-plans-setrenewable-energy-utility/

Mbarek, M.B., Saidi, K., Feki, R., 2016. How Effective Are Renewable Energy in Addition of Economic Growth and Curbing $\mathrm{CO}_{2}$ Emissions in the Long Run? A Panel Data Analysis for Four Mediterranean Countries. Journal of the Knowledge Economy, 1-13.

Menyah, K., Wolde-Rufael, Y., 2010. $\mathrm{CO}_{2}$ emissions, nuclear energy, renewable energy and economic growth in the US. Energy Policy, 38(6), 2911-2915.

Ministry of Power, 2015. National Renewable Energy and Energy Efficiency Policy (NREEEP): Approved By FEC for the Electricity Sector. Federal Republic of Nigeria.

Noi, H., 2016. Renewable energy - Viet Nam's power future. United Nations Development Programme. May 24, 2016. Retrieved from: http://www.vn.undp.org/content/vietnam/en/home/presscenter/pressreleases/2016/05/24/rene wable-energy-viet-nam-s-power-future.html

Ozturk, I., Bilgili, F., 2015. Economic growth and biomass consumption nexus: Dynamic panel analysis for Sub-Sahara African countries. Applied Energy, 137, 110-116.

Pao, H.T., Fu, H.C., 2013a. Renewable energy, non-renewable energy and economic growth in Brazil. Renewable and Sustainable Energy Reviews, 25, 381-392.

Pao, H.T., Fu, H.C., 2013b. The causal relationship between energy resources and economic growth in Brazil. Energy Policy, 61, 793-801.

Paramati, S.R., Alam, M.S., Chen, C.F., 2016. The Effects of Tourism on Economic Growth and CO2 Emissions A Comparison between Developed and Developing Economies. Journal of Travel Research, 0047287516667848.

Paramati, S.R., Apergis, N., Ummalla, M, 2017. Financing clean energy projects through domestic and foreign capital: The role of political cooperation among the EU, the G20 and OECD countries. Energy Economics, 61, 62-71.

Paramati, S.R., Shahbaz, M., Alam, M.S., 2017. Does tourism degrade environmental quality? A comparative study of Eastern and Western European Union. Transportation Research Part D: Transport and Environment, 50, 1-13. 
Paramati, S.R., Ummalla, M., Apergis, N., 2016. The effect of foreign direct investment and stock market growth on clean energy use across a panel of emerging market economies. Energy Economics, 56, 29-41.

Pedroni, P., 2000. Fully modified OLS for heterogeneous cointegrated panels," in Baltagi, B.H. ed., Nonstationary panels, panel cointegration and dynamic panels, 15, Amsterdam: Elsevier, 93130.

Pedroni, P., 2001a. Fully modified OLS for heterogeneous cointegrated panels. Advances in Econometrics, 15, 93-130.

Pedroni, P., 2001b. Purchasing power parity tests in cointegrated panels. Review of Economics and Statistics, 83(4), 727-731.

Penkett, S., Jones, B.M.R., Brich, K.A., Eggleton, A.E., 1979. The importance of atmospheric ozone and hydrogen peroxide in oxidising sulphur dioxide in cloud and rainwater. Atmospheric Environment, 13(1), 123-137.

Pesaran, M.H., 2004. General diagnostic tests for cross section dependence in panels. University of Cambridge, Faculty of Economics, Cambridge Working Papers in Economics No. 0435.

Raskin, P.D., 1995. Methods for estimating the population contribution to environmental change. Ecological Economics, 15(3), 225-233.

Renewable Energy Policy Network for the 21st Century (REN21), 2016. Renewables 2013 Global Status Report. Paris.

Sadorsky, P., 2009. Renewable energy consumption and income in emerging economies. Energy Policy, 37(10), 4021-4028.

Sebri, M., Ben-Salha, O., 2014. On the causal dynamics between economic growth, renewable energy consumption, $\mathrm{CO}_{2}$ emissions and trade openness: fresh evidence from BRICS countries. Renewable and Sustainable Energy Reviews, 39, 14-23.

Shahbaz, M., Mahalik, M.K., Shah, S.H., Sato, J.R., 2016. Time-varying analysis of $\mathrm{CO}_{2}$ emissions, energy consumption, and economic growth nexus: Statistical experience in next 11 countries. Energy Policy, 98, 33-48.

Shin, S., 2015. Four point plan for promoting renewable energy in South Korea. Center for Energy \& Environmental Policy. Retrieved from: http://ceep.udel.edu/four-point-plan-for-promotingrenewable-energy-in-south-korea/

Silva, S., Soares, I., Pinho, C., 2012. The impact of renewable energy sources on economic growth and $\mathrm{CO}_{2}$ emissions-a SVAR approach. European Research Studies, 15(4), 133-144.

Sinha, A., Bhattacharya, J., 2016. Environmental Kuznets Curve estimation for $\mathrm{NO}_{2}$ emission: A case of Indian cities. Ecological Indicators, 67, 1-11.

Sinha, A., Bhattacharya, J., 2017. Environmental Kuznets Curve estimation for $\mathrm{SO}_{2}$ emission: A case of Indian cities. Ecological Indicators, 72, 881-894.

Tiwari, A.K., 2011. A structural VAR analysis of renewable energy consumption, real GDP and $\mathrm{CO}_{2}$ emissions: evidence from India. Economics Bulletin, 31(2), 1793-1806.

Tugcu, C.T., Ozturk, I., Aslan, A., 2012. Renewable and non-renewable energy consumption and economic growth relationship revisited: evidence from G7 countries. Energy Economics, 34(6), 1942-1950.

U.S. Energy Information Administration (EIA), 2012. International Energy Statistics. Retrieved from: http://www.eia.gov/cfapps/ipdbproject/IEDIndex3.cfm?tid=1\&pid=1\&aid=8.

Watkins, W.M., Mosobo, M., 1993. Treatment of Plasmodium falciparum malaria with pyrimethamine-sulfadoxine: selective pressure for resistance is a function of long elimination half-life. Transactions of the Royal Society of Tropical Medicine and Hygiene, 87(1), 75-78. 
Wheeler, E., Desai, M., 2016. Iran's Renewable Energy Potential. Middle East Institute. Jan 26, 2016. Retrieved from: http://www.mei.edu/content/article/iran\%E2\%80\%99s-renewable-energypotential.

Whitby, K.T., 1978. The physical characteristics of sulfur aerosols. Atmospheric Environment, 12(1), 135-159.

World Bank, 2012. World Development Indicators. Retrieved from: http://data.worldbank.org/indicator.

Yıldırım, E., Sukruoglu, D., Aslan, A., 2014. Energy consumption and economic growth in the next 11 countries: The bootstrapped autoregressive metric causality approach. Energy Economics, 44, 14-21.

York, R., Rosa, E.A., Dietz, T., 2002. Bridging environmental science with environmental policy: Plasticity of population, affluence, and technology. Social Science Quarterly, 83(1), 18-34.

Zeb, R., Salar, L., Awan, U., Zaman, K., Shahbaz, M., 2014. Causal links between renewable energy, environmental degradation and economic growth in selected SAARC countries: Progress towards green economy. Renewable Energy, 71, 123-132. 


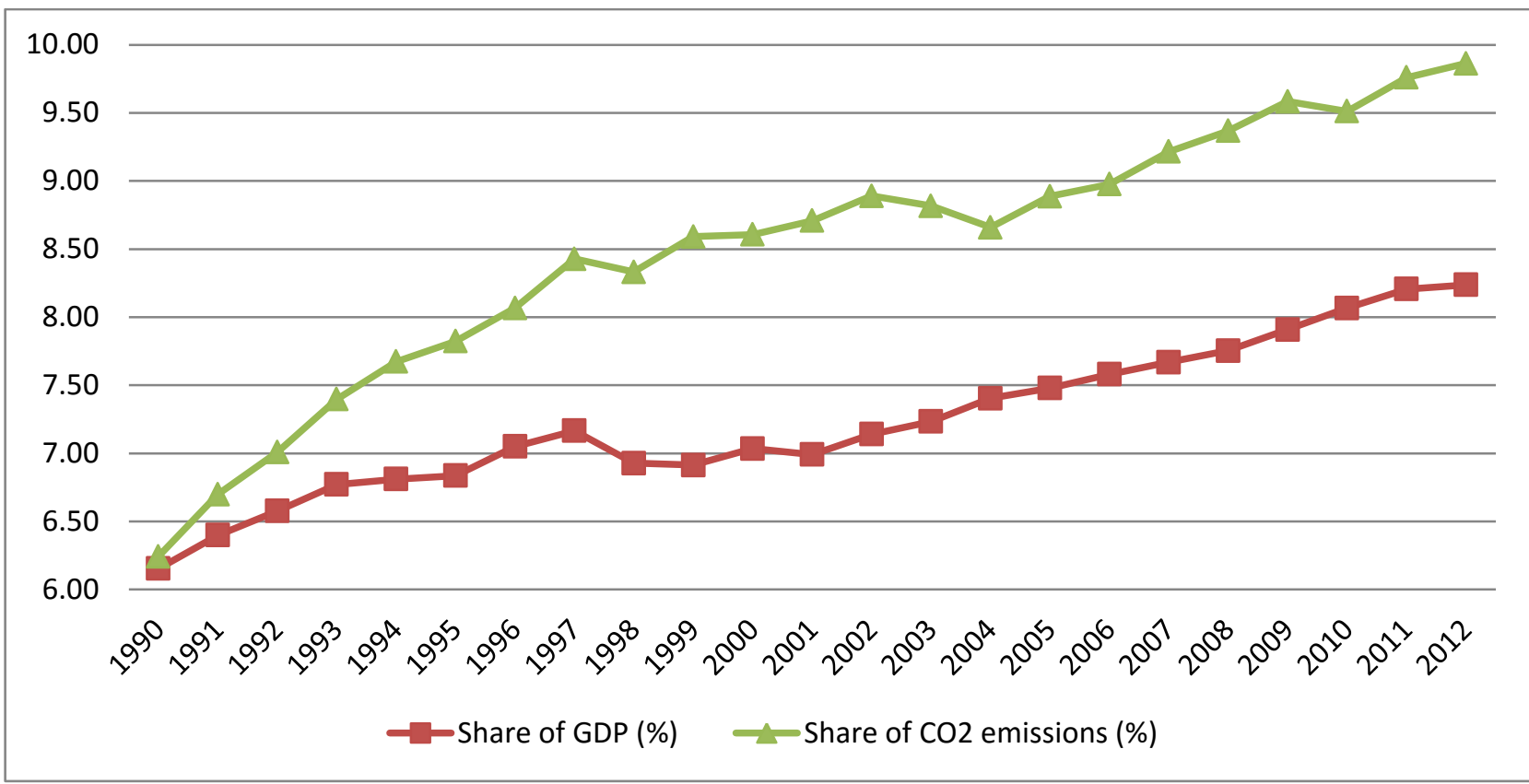

Figure 1: Share of Next 11 countries' GDP and $\mathrm{CO}_{2}$ emissions in the world

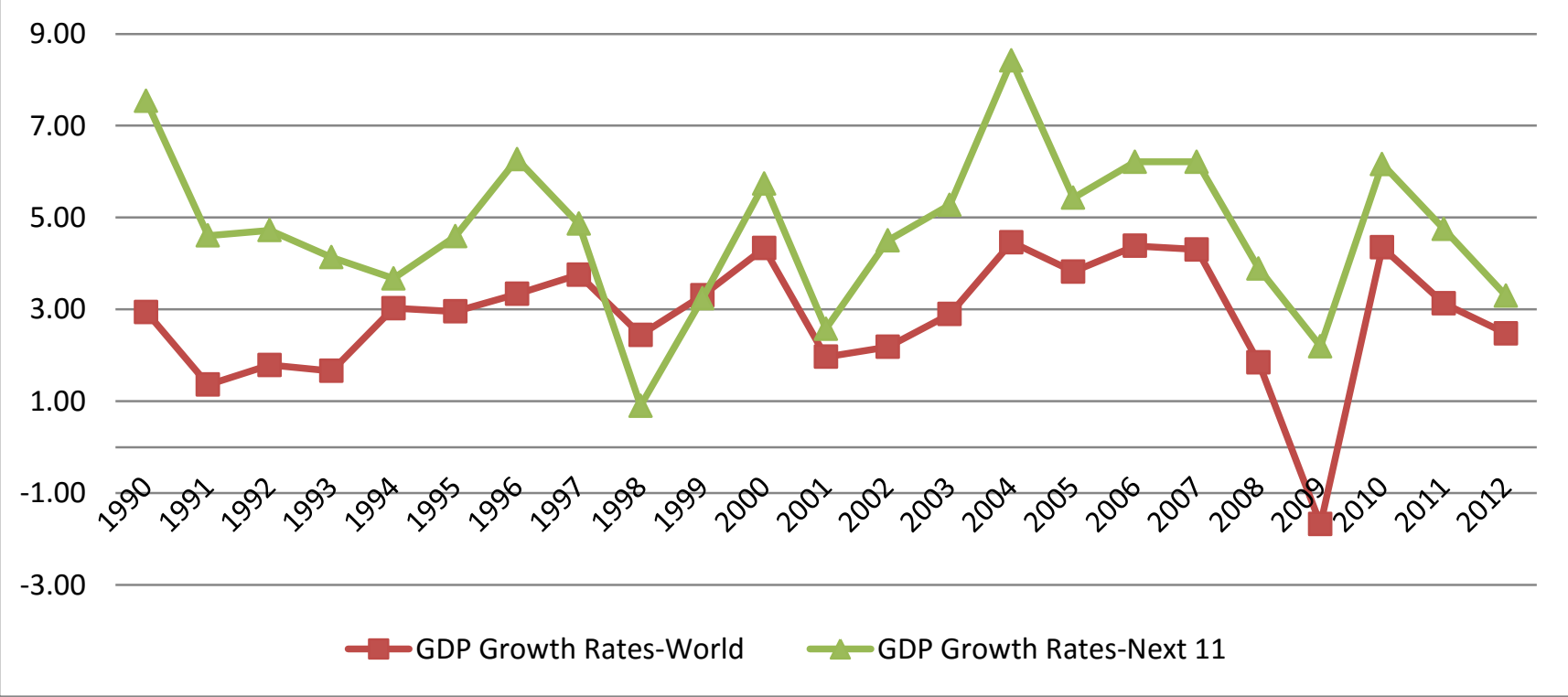

Figure 2: Comparison of GDP growth rate between World and Next 11 economies 
Table 1: Panel correlation matrix

\begin{tabular}{lllllllll}
\hline & CDE & EA & NREC & REC & CAP & LBR & PI & POP \\
\hline CDE & 1.000 & & & & & & & \\
EA & 0.911 & 1.000 & & & & & & \\
NREC & 0.984 & 0.888 & 1.000 & & & & & \\
REC & -0.321 & -0.146 & -0.398 & 1.000 & & & & \\
CAP & 0.906 & 0.958 & 0.904 & -0.250 & 1.000 & & & \\
LBR & -0.174 & -0.044 & -0.170 & 0.712 & -0.005 & 1.000 & & \\
PI & 0.871 & 0.909 & 0.855 & -0.454 & 0.889 & -0.418 & 1.000 & \\
POP & -0.161 & -0.062 & -0.169 & 0.779 & -0.103 & 0.905 & -0.473 & 1.000 \\
\hline
\end{tabular}

Note: Correlations are estimated using log data.

Table 2: Results of cross section dependence test

\begin{tabular}{lll}
\hline & p-value & Lag length \\
\hline CDE & 0.931 & 4 \\
EA & 0.132 & 2 \\
NREC & 0.172 & 3 \\
REC & 0.905 & 1 \\
CAP & 0.322 & 1 \\
LBR & 0.406 & 1 \\
PI & 0.118 & 1 \\
POP & 0.962 & 2 \\
\hline
\end{tabular}


Table 3: Panel unit root tests

\begin{tabular}{|c|c|c|c|c|c|c|c|c|}
\hline \multirow[t]{3}{*}{ Variables } & \multicolumn{4}{|c|}{ LLC test } & \multicolumn{4}{|c|}{ IPS test } \\
\hline & \multicolumn{2}{|c|}{ Level } & \multicolumn{2}{|c|}{ First difference } & \multicolumn{2}{|c|}{ Level } & \multicolumn{2}{|c|}{ First difference } \\
\hline & Statistic & Prob. & Statistic & Prob. & Statistic & Prob. & Statistic & Prob. \\
\hline $\mathrm{CDE}$ & 0.309 & 0.621 & $-7.228 * * *$ & 0.000 & 1.760 & 0.961 & $-7.284 * * *$ & 0.000 \\
\hline EA & 0.457 & 0.676 & $-3.852 * * *$ & 0.000 & 3.175 & 0.999 & $-4.385 * * *$ & 0.000 \\
\hline NREC & -1.243 & 0.107 & $-6.896 * * *$ & 0.000 & 1.647 & 0.950 & $-7.363 * * *$ & 0.000 \\
\hline REC & 1.452 & 0.927 & $-3.311 * * *$ & 0.001 & 1.974 & 0.976 & $-4.682 * * *$ & 0.000 \\
\hline CAP & 1.681 & 0.954 & $-6.012 * * *$ & 0.000 & 2.664 & 0.996 & $-7.217 * * *$ & 0.000 \\
\hline LBR & -1.541 & 0.062 & $-2.324 * * *$ & 0.010 & 3.085 & 0.999 & $-3.806 * * *$ & 0.000 \\
\hline PI & 0.173 & 0.569 & $-3.263 * * *$ & 0.001 & 3.518 & 1.000 & $-4.108 * * *$ & 0.000 \\
\hline POP & 2.526 & 0.994 & $-5.378 * * *$ & 0.000 & 2.724 & 0.997 & $-3.264 * * *$ & 0.001 \\
\hline
\end{tabular}

where $* *$ and $* * *$ indicate the rejection of null hypothesis of a unit root at the $5 \%$ and $1 \%$ significance level, respectively. 
Table 4: Johansen-Fisher panel cointegration test

\begin{tabular}{lllllllll}
\hline Hypothesized & \multicolumn{10}{c}{ Fisher Statistics } \\
\hline & \multicolumn{1}{l}{$E A=f(C A P, L B R, N R E C, R E C)$} \\
\hline No. of CE(s) & trace test & Prob. & max-eigen test & Prob. & trace test & Prob. & max-eigen test & Prob. \\
\hline None & $200.900^{* * *}$ & 0.000 & $96.930^{* * *}$ & 0.000 & $404.200^{* * *}$ & 0.000 & $329.100^{* * * *}$ & 0.000 \\
At most 1 & $124.400^{* * *}$ & 0.000 & $66.530^{* * *}$ & 0.000 & $153.300^{* * *}$ & 0.000 & $83.020^{* * *}$ & 0.000 \\
At most 2 & $75.210^{* * *}$ & 0.000 & $42.400^{* * *}$ & 0.006 & $89.390^{* * *}$ & 0.000 & $58.230^{* * *}$ & 0.000 \\
At most 3 & $52.850^{* * *}$ & 0.000 & $43.900^{* * *}$ & 0.004 & $51.220^{* * *}$ & 0.000 & $53.610^{* * *}$ & 0.000 \\
At most 4 & $36.970^{* *}$ & 0.024 & $36.970^{* *}$ & 0.024 & 20.240 & 0.568 & 20.240 & 0.568 \\
\hline
\end{tabular}

Note: $* *$ and $* * *$ indicate the rejection of no cointegration at the $5 \%$ and $1 \%$ significance level, respectively.

Table 5: Panel fully modified ordinary least squares (FMOLS) method

\begin{tabular}{|c|c|c|c|}
\hline Variable & Coefficient & t-Statistic & Prob. \\
\hline \multicolumn{4}{|c|}{$E A=f(C A P, L B R, N R E C, R E C)$} \\
\hline CAP & $0.202 * * *$ & 13.534 & 0.000 \\
\hline LBR & $0.699 * * *$ & 111.749 & 0.000 \\
\hline NREC & $0.149 * * *$ & 8.394 & 0.000 \\
\hline REC & $0.157 * * *$ & 14.085 & 0.000 \\
\hline \multicolumn{4}{|c|}{$C D E=f(P O P, P I, N R E C R E C)$} \\
\hline POP & $-0.201 * * *$ & -86.063 & 0.000 \\
\hline PI & $-0.085^{* * *}$ & -36.112 & 0.000 \\
\hline NREC & $1.076 * * *$ & 241.893 & 0.000 \\
\hline REC & $-0.052 * * *$ & -18.923 & 0.000 \\
\hline
\end{tabular}

Note: $* * *$ indicate the significance level at the $1 \%$. 
Table 6: Pairwise Dumitrescu-Hurlin panel causality test

\begin{tabular}{llll}
\hline Null Hypothesis: & W-Stat. & Zbar-Stat. & Prob. \\
\hline EA does not homogeneously cause CDE & 1.669 & 1.029 & 0.304 \\
CDE does not homogeneously cause EA & 1.198 & 0.137 & 0.891 \\
NREC does not homogeneously cause CDE & 6.136 & $2.244^{* *}$ & 0.025 \\
CDE does not homogeneously cause NREC & 3.936 & 0.298 & 0.766 \\
REC does not homogeneously cause CDE & 0.823 & -0.571 & 0.568 \\
CDE does not homogeneously cause REC & 3.007 & $3.559^{* * *}$ & 0.000 \\
PI does not homogeneously cause CDE & 1.717 & 1.120 & 0.263 \\
CDE does not homogeneously cause PI & 1.368 & 0.459 & 0.646 \\
NREC does not homogeneously cause EA & 1.199 & 0.140 & 0.888 \\
EA does not homogeneously cause NREC & 1.628 & 0.951 & 0.341 \\
REC does not homogeneously cause EA & 1.173 & 0.091 & 0.928 \\
EA does not homogeneously cause REC & 0.374 & -1.420 & 0.156 \\
REC does not homogeneously cause NREC & 1.511 & 0.730 & 0.465 \\
NREC does not homogeneously cause REC & 2.305 & $2.232 * *$ & 0.026 \\
PI does not homogeneously cause NREC & 1.608 & 0.915 & 0.360 \\
NREC does not homogeneously cause PI & 1.368 & 0.459 & 0.646 \\
PI does not homogeneously cause REC & 0.392 & -1.386 & 0.166 \\
REC does not homogeneously cause PI & 1.221 & 0.182 & 0.855 \\
\hline
\end{tabular}

Note: $* *$ and $* * *$ indicate the significance level at the $5 \%$ and $1 \%$, respectively. 
Table 7: Country-specific long-run output elasticities

\begin{tabular}{|c|c|c|c|c|c|c|c|c|}
\hline Country & Variable & Constant & CAP & LBR & NREC & REC & R-squared & Adj. R-squared \\
\hline \multirow[t]{2}{*}{ Bangladesh } & Coefficient & $10.082 * *$ & $0.793 * * *$ & $-0.876 * *$ & -0.084 & $0.944 * * *$ & 0.997 & 0.997 \\
\hline & Prob. & 0.037 & 0.000 & 0.023 & 0.186 & 0.000 & & \\
\hline \multirow[t]{2}{*}{ Egypt } & Coefficient & $8.653 * * *$ & $0.104 * * *$ & $0.551 * * *$ & $0.347 * * *$ & $0.436 * * *$ & 0.995 & 0.993 \\
\hline & Prob. & 0.000 & 0.000 & 0.000 & 0.000 & 0.000 & & \\
\hline \multirow[t]{2}{*}{ Indonesia } & Coefficient & $8.312 * * *$ & $0.332 * * *$ & $0.300 * * *$ & $0.415 * * *$ & $0.274 * * *$ & 0.998 & 0.998 \\
\hline & Prob. & 0.000 & 0.000 & 0.000 & 0.000 & 0.010 & & \\
\hline \multirow[t]{2}{*}{ Iran } & Coefficient & $23.480 * * *$ & $0.232 * * *$ & $-0.266^{* * * *}$ & $0.565^{* * *}$ & $0.064 * * *$ & 0.990 & 0.988 \\
\hline & Prob. & 0.000 & 0.000 & 0.000 & 0.000 & 0.000 & & \\
\hline \multirow[t]{2}{*}{ Korea } & Coefficient & $-44.824 * * *$ & $0.145^{* * *}$ & $4.016 * * *$ & $-0.165 * *$ & $0.058 * * *$ & 0.994 & 0.993 \\
\hline & Prob. & 0.000 & 0.000 & 0.000 & 0.001 & 0.000 & & \\
\hline \multirow[t]{2}{*}{ Mexico } & Coefficient & $16.054 * * *$ & $0.138 * * *$ & $0.340 * * *$ & $0.620 * * *$ & $0.063 * * *$ & 0.996 & 0.995 \\
\hline & Prob. & 0.000 & 0.000 & 0.000 & 0.000 & 0.006 & & \\
\hline \multirow[t]{2}{*}{ Nigeria } & Coefficient & $27.773 * * *$ & $0.096 * * *$ & $-6.525 * * *$ & 0.013 & $7.395 * * *$ & 0.971 & 0.965 \\
\hline & Prob. & 0.000 & 0.002 & 0.000 & 0.839 & 0.000 & & \\
\hline \multirow[t]{2}{*}{ Pakistan } & Coefficient & $1.915 * * *$ & $0.195 * * *$ & $0.720 * * *$ & $0.064 * * *$ & $0.455 * * *$ & 0.997 & 0.997 \\
\hline & Prob. & 0.000 & 0.000 & 0.000 & 0.000 & 0.000 & & \\
\hline \multirow[t]{2}{*}{ Philippines } & Coefficient & $-2.113 * *$ & $0.431 * * *$ & $1.325^{* * *}$ & $-0.554 * * *$ & $-0.440 * * *$ & 0.994 & 0.992 \\
\hline & Prob. & 0.032 & 0.000 & 0.000 & 0.000 & 0.000 & & \\
\hline \multirow[t]{2}{*}{ Turkey } & Coefficient & $17.776^{* * *}$ & $0.178 * * *$ & $0.274 * * *$ & $0.619 * * *$ & -0.043 & 0.996 & 0.995 \\
\hline & Prob. & 0.000 & 0.000 & 0.004 & 0.000 & 0.532 & & \\
\hline \multirow[t]{2}{*}{ Vietnam } & Coefficient & $-10.531 * * *$ & $-0.124 * * *$ & $2.242 * * *$ & $0.294 * * *$ & -0.067 & 0.998 & 0.998 \\
\hline & Prob. & 0.000 & 0.000 & 0.000 & 0.000 & 0.203 & & \\
\hline
\end{tabular}

Note: $* *$ and $* * *$ indicate the significance level at the $5 \%$ and $1 \%$, respectively. 
Table 8: Country-specific long-run $\mathrm{CO}_{2}$ emission elasticities

\begin{tabular}{|c|c|c|c|c|c|c|c|c|}
\hline Country & Variable & Constant & POP & PI & NREC & REC & R-squared & Adj. R-squared \\
\hline \multirow[t]{2}{*}{ Bangladesh } & Coefficient & $7.529 * * *$ & $-0.126^{* * *}$ & $-0.030 * *$ & $1.046^{* * *}$ & $-0.070 * *$ & 1.000 & 0.999 \\
\hline & Prob. & 0.000 & 0.007 & 0.014 & 0.000 & 0.041 & & \\
\hline \multirow[t]{2}{*}{ Egypt } & Coefficient & $6.089 * * *$ & $-0.125^{*}$ & $0.176 * * *$ & $0.805^{* * *}$ & $-0.076 * * *$ & 0.998 & 0.998 \\
\hline & Prob. & 0.000 & 0.058 & 0.000 & 0.000 & 0.001 & & \\
\hline \multirow[t]{2}{*}{ Indonesia } & Coefficient & $-15.660 * * *$ & $0.911 * *$ & -0.019 & $0.704 * * *$ & 0.207 & 0.998 & 0.998 \\
\hline & Prob. & 0.003 & 0.016 & 0.797 & 0.000 & 0.485 & & \\
\hline \multirow[t]{2}{*}{ Iran } & Coefficient & $-14.071 * * *$ & $0.908 * * *$ & $0.298 * * *$ & $0.513 * * *$ & $0.019 * * *$ & 0.998 & 0.997 \\
\hline & Prob. & 0.000 & 0.000 & 0.000 & 0.000 & 0.000 & & \\
\hline \multirow[t]{2}{*}{ Korea } & Coefficient & $34.259 * * *$ & $-1.728 * * *$ & -0.054 & $1.109 * * *$ & $0.073 * * *$ & 0.989 & 0.986 \\
\hline & Prob. & 0.000 & 0.000 & 0.246 & 0.000 & 0.000 & & \\
\hline \multirow[t]{2}{*}{ Mexico } & Coefficient & -7.212 & 0.333 & $0.491 *$ & 0.421 & 0.141 & 0.982 & 0.977 \\
\hline & Prob. & 0.308 & 0.308 & 0.092 & 0.235 & 0.160 & & \\
\hline \multirow[t]{2}{*}{ Nigeria } & Coefficient & -0.879 & $2.297 * * *$ & $0.182^{* *}$ & $0.605 * * *$ & $-2.598 * * *$ & 0.554 & 0.449 \\
\hline & Prob. & 0.842 & 0.010 & 0.012 & 0.000 & 0.002 & & \\
\hline \multirow[t]{2}{*}{ Pakistan } & Coefficient & $4.276 * * *$ & $0.131 * * *$ & $-0.253 * * *$ & $1.013 * * *$ & $-0.062^{*}$ & 0.999 & 0.999 \\
\hline & Prob. & 0.000 & 0.000 & 0.000 & 0.000 & 0.084 & & \\
\hline \multirow[t]{2}{*}{ Philippines } & Coefficient & $3.701 * *$ & $0.204 * * *$ & $-0.115 * * *$ & $0.872 * * *$ & $-0.177 * * *$ & 0.982 & 0.977 \\
\hline & Prob. & 0.011 & 0.001 & 0.000 & 0.000 & 0.000 & & \\
\hline \multirow[t]{2}{*}{ Turkey } & Coefficient & $16.100^{* * *}$ & $-0.644 * * *$ & $0.029 * * *$ & $1.099 * * *$ & $-0.048 * * *$ & 0.999 & 0.999 \\
\hline & Prob. & 0.000 & 0.000 & 0.000 & 0.000 & 0.000 & & \\
\hline \multirow[t]{2}{*}{ Vietnam } & Coefficient & $15.869 * * *$ & $-0.497 * *$ & -0.060 & $1.042 * * *$ & $-0.153 * * *$ & 0.998 & 0.998 \\
\hline & Prob. & 0.000 & 0.013 & 0.405 & 0.000 & 0.001 & & \\
\hline
\end{tabular}

Note:*,** and $* * *$ indicate the significance level at the $10 \%, 5 \%$ and $1 \%$, respectively. 